\title{
Three Different North American Siskin/Goldfinch Evolutionary Radia- tions (Genus Carduelis): Pine Siskin Green Morphs and European Siskins in America
}

\author{
Antonio Arnaiz-Villena*, Cristina Areces, Diego Rey, Mercedes Enríquez-de-Salamanca, Javier \\ Alonso-Rubio and Valentín Ruiz-del-Valle
}

Dept. Immunology, University Complutense, The Madrid Regional Blood Center, Madrid, Spain.

\begin{abstract}
Three separate and parallel North American Carduelis evolutionary radiations have been identified. North American siskin radiation (starting about 2.7 million years ago) comprises siskin, Antillean siskin, black-capped siskin, pine siskin and pine siskin perplexus. C. spinus could have passed to America through the Beringia or Greenland coast and, during Pliocene Epoch, reached the Antilles and evolved into Antillean siskin (C. dominicensis), endemic to Hispaniola Island. It is ancestor of pine siskin. Pine Siskin, also a sister taxon of $C$. spinus, thrives in North America from Alaska to Guatemala since about 0.2 MYA. It lives below the Mexican Isthmus in the highlands from northern Chiapas (Mexico) to western Guatemala. Black-capped siskin (C. atriceps) is a sister species of $C$. spinus, with which it shares habitat and territory. $C$. pinus green-backed morphs may have been mistaken by C. atriceps which is a grey-backed finch. Mesoamerican goldfinch radiation (starting about 5 million years ago) includes C. tristis (American goldfinch), C. psaltria (lesser goldfinch) and C. lawrencei (Lawrence's goldfinch). They all thrive in western United States and Mexico, down to northern South America. C. psaltria is a North American bird that colonized South American habitats to North Peru and evolved into darker head and back while going southwards. South American siskin radiation started about 3.5 million years ago; parental C. notata thrives in Mexican mountains and successfully colonized South America, giving rise to this radiation. South American Carduelis radiation occurred only when mesothermal plants from the Rocky Mountains invaded the Andean spine after emergence of the Panama Isthmus.
\end{abstract}

Keywords: American goldfinch, American siskins, Carduelis, goldfinches phylogeny, phylogeography, Pine siskin green morphs, siskins spinus.

\section{INTRODUCTION}

The evolutionary histories of songbirds (class Aves, order Passeriformes, suborder Passeri) have been broadly studied. Their phenotypic behaviour and molecular evolution are not always concordant [1,2]. Thus, the parallelism in morphology and behavioural characters may lead to shared features among non-closely genetically related species occurring in similar or quasi-identical environments, and conversely, distinct features may occur among genetic sister taxa thriving under different environments. Evidence of this phenotypic plasticity has already been documented for other bird species [3-7]. Therefore some genetic and/or phenetic traits apparently may not correlate with the evolutionary histories of the birds under study.

Genus Carduelis (family Fringillidae, subfamily Fringillinae, tribe Carduelini) includes goldfinches, siskins, redpolls, greenfinches, and crossbills, among others [8]. It comprises over 30 species, and is widespread all over the World with the exception of Subsaharian Africa and Australia. It

*Address correspondence to this author at the Departamento de Inmunologia, Facultad de Medicina, Universidad Complutense, Pabellon 5, planta 4. Avda. Complutense s/n, 28040 Madrid, Spain;

Tel: +34 913 941632; Fax: +34 91301 73 56; E-mail: aarnaiz@med.ucm.es; Webpage: http://chopo.pntic.mec.es/biolmol/ belongs to the Fringillidae family of birds which also includes many sparrows, bramblings, and chaffinches [9-11]. Many of the species comprised within this genus and other genera have recently been classified by using Molecular Systematic and the mitochondrial cytochrome b (cyt-b) gene. This orthologous gene has proved to be helpful for defining evolutionary relationships among relatively distant and closely related birds, even at the subspecies level $[12,13]$. In order to complete the cyt-b phylogeny of North and South American Carduelis taxa, several Carduelis species/subspecies have been analyzed together (Table 1), in order to detect the evolutionary relationship of American Carduelis species, denominated siskins with the exception of the American goldfinch (C. tristis) [14]. Also C. pinus perplexus has been included regardless of its uncertain phenotypic taxonomic status. In addition, Pine siskin, Black-capped siskin, Antillean siskin and other North American songbirds have been related to South American siskins and other Eurasian songbirds like Eurasiatic Twite and Linnet included in the genus Carduelis according to their mtDNA structure [14-16].

In summary, in the present work, a genetic analysis of these species has been carried out by studying their cyt-b sequence variation aiming to relate these Carduelis species and defining North and South American Carduelis evolutionary radiations. 


\section{MATERIALS AND METHODOLOGY}

\section{Bird Samples, DNA Extraction, Amplification and Sequencing}

We collected and analyzed 27 Carduelis species as well as 4 subspecies (Table 1). Blood samples (2-3 drops) were obtained from wild birds in their natural thriving areas, and frozen in an ethylenediaminetetraacetic acid (EDTA) solu- tion until use. DNA extraction was performed using a standard Phenol-Chloroform methodology [17] or a commercial DNA purification kit (QuickGene DNA Whole Blood Kit S, FUJIFILM, Tokyo, Japan). 924 base pairs of the cyt-b gene were specifically amplified by polymerase chain reaction (PCR) with the primers L14841 and H15767 [18] in a Mastercycler ep gradient $S$ thermal cycler (EPPENDORF, Hamburg, Germany). The final reaction volume was $20 \mu \mathrm{l}$, containing 200-400 ng of whole DNA and the rest of PCR re-

Table 1.`Genus Carduelis Species Used in the Present Study. All Samples and Sequences Belong to Authors. All Photographs were Taken Out by Antonio Arnaiz-Villena

\begin{tabular}{|c|c|c|c|}
\hline Name & English name & Distribution & GenBank \\
\hline Carduelis atrata & Black siskin & S. América & L76385 \\
\hline Carduelis atriceps & Black-capped siskin & Mexico, Guatemala & AF342863 \\
\hline Carduelis barbata & Black-chinned siskin & Chile, Argentina & L77868 \\
\hline Carduelis carduelis caniceps & Grey-crowned goldfinch & Asia & L76388 \\
\hline Carduelis carduelis parva & Eurasian goldfinch & W. Europe & L76387 \\
\hline Carduelis chloris & European greenfinch & Eurasia, N. Africa & L76297 \\
\hline Carduelis citrinella & Citril finch & Europe & L77872 \\
\hline Carduelis flammea & Common redpoll & N. Eurasia, N. America & L76386 \\
\hline Carduelis flavirostris & Twite & Eurasia & U83199 \\
\hline Carduelis hornemanni & Hoary redpoll & N. Eurasia, N. América & U83201 \\
\hline Carduelis lawrencei & Lawrence's goldfinch & USA, Mexico & L76392 \\
\hline Carduelis magellanica & Hooded siskin & S. América & U79016 \\
\hline Carduelis notata & Black-headed siskin & Central America & U79019 \\
\hline Carduelis olivacea & Olivaceous siskin & Andean spine & L77871 \\
\hline Carduelis spinescens & Andean siskin & Colombia, Venezuela, Bolivia & U79017 \\
\hline Carduelis spinoides & Black-headed greenfinch & Asia & U79018 \\
\hline Carduelis spinus & Eurasian siskin & Eurasia, N. Africa (N. América) & L76391 \\
\hline Carduelis tristis & American goldfinch & N. America & U79022 \\
\hline Carduelis xanthogastra & Yellow-bellied siskin & Andean spine & L76389 \\
\hline Carduelis yarrelli & Yellow-faced siskin & Brasil & U83200 \\
\hline Carpodacus mexicanus (outgroup) & House finch & N. America & AF342865 \\
\hline
\end{tabular}


agents according to the requirements of the polymerase used (Taq DNA polymerase, recombinant, INVITROGEN, Carlsbad, CA, USA). The PCR conditions consisted of one denaturation cycle $\left(95^{\circ} \mathrm{C}, 5\right.$ minutes), followed by 45 cycles of denaturation $\left(96^{\circ} \mathrm{C}, 30\right.$ seconds), primer annealing $\left(50^{\circ} \mathrm{C}, 35\right.$ seconds) and polymerase extension $\left(72^{\circ} \mathrm{C}, 70\right.$ seconds) steps, and a final extension cycle $\left(72^{\circ} \mathrm{C}, 20 \mathrm{~min}\right.$.). Amplification products were separated by electrophoresis in $2 \%$ agarose and the fragments purified with a commercial kit (Mini Elute Gel Extraction Kit, QUIAGEN, Hilden, Germany). The sequencing process was carried out in an Applied Biosystems 970 Automated Sequencer using the primers L14841, L15299 and H15149 [18]. At least, two independent amplifications (and further sequencing) were performed for each sample to confirm the sequences obtained.

\section{Statistical Analyses and Time Calculation Hypothesis}

DNA sequences were aligned and checked for stop codons with MEGA 3.1 computer program [19] for further phylogenetic calculations. The final length of the sequences used was 924 nucleotides. The chaffinch, Fringilla coelebs (family Fringillidae, subfamily Fringillinae), was chosen as outgroup to root the phylogenetic dendrograms, which were constructed using linearized Bayesian Inference (BI) methodology. The BI phylogram was calculated with MrBayes 3.1.2 computer program [20]. The model of nucleotide substitution used was GTR $+\mathrm{I}+\mathrm{G}$, that is, a general time reversible model (which considers six different nucleotide substitution types), implemented with the proportion of invariable sites and the gamma distribution of rates at variable sites. The default settings were left as priors for the analysis. Two independent runs (with one cold and three heated chains each) were performed and the analysis was stopped after 4 million generations, being the standard deviation of split frequencies around 0.01 . The trees were sampled every 100 generations along the Markov Chain-Monte Carlo process, and the first 10,000 samples (25\%) were discarded as burnin. The posterior probability values indicate the robustness of the nodes (Fig. 1). The likelihood scores estimated for that model were used, and linearized estimating the branch lengths according to the model proposed by Thorne [21], which allows the rates not to be constant among the evolutionary lineages. The robustness of the nodes was obtained after 1,000 bootstrap replications.

It was estimated in a previous work that the chaffinch separated from the greenfinches about 16.5 million years ago (MYA) [15]. Initially, a mixed external fossil and molecular record divergence time (pheasant/chicken) was used to calibrate our dendrograms. A continuum of small songbirds speciation was found during the Miocene, Pliocene and Pleistocene Epochs [15]. Also, last glaciations may have separated western European siskins (C. spinus) from the Far East subspecies by an ice-induced vicariance effect [22]. A linearized Maximum Likelihood (ML) tree was constructed to infer the hypothetical evolutive radiation times of appearance on Earth (mtDNA phylogeny of North American $C$. pinus) [16].

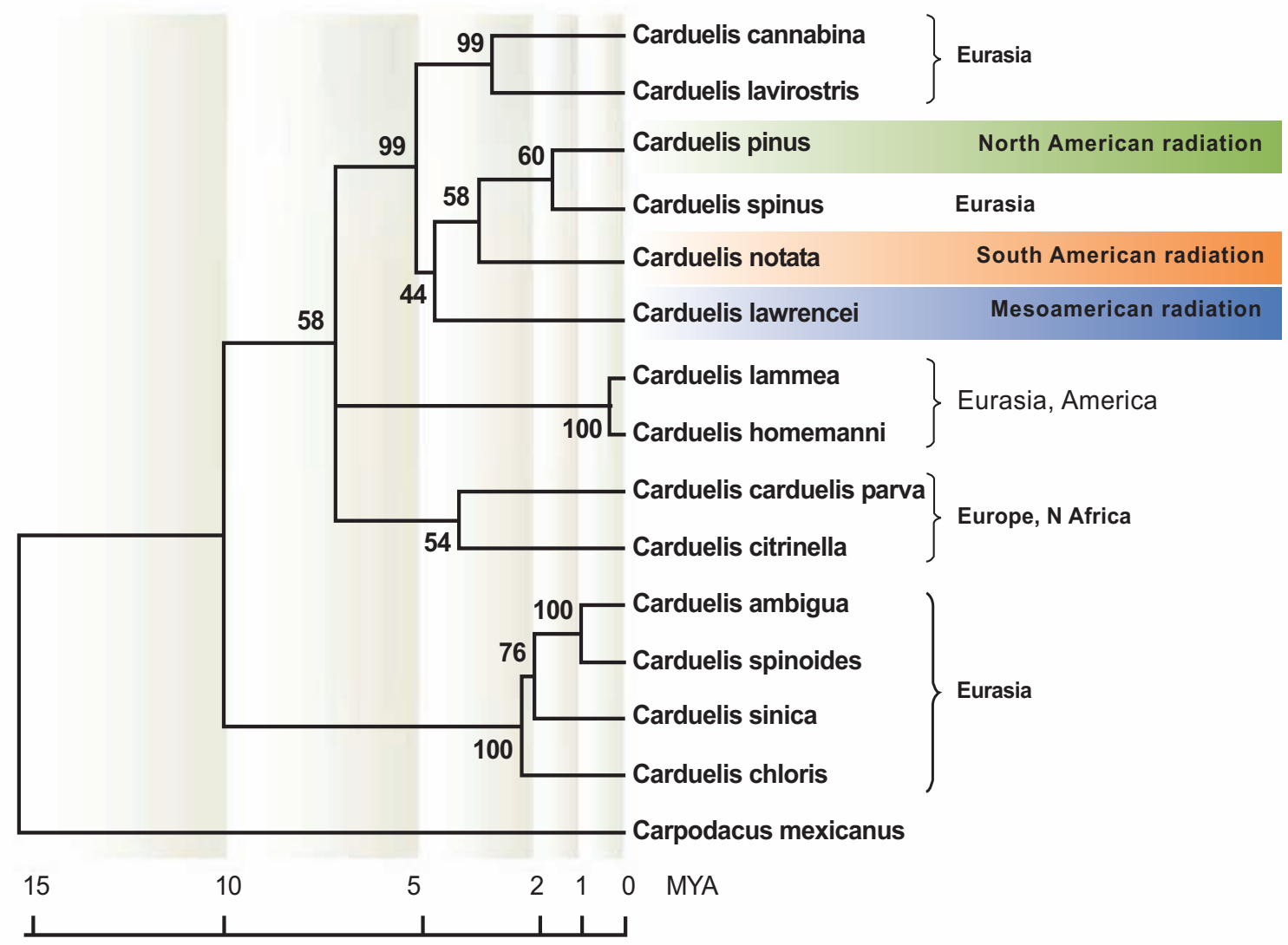

Fig. (1). Bayesian inference linearized cyt-b phylogram showing the three evolutionary radiations of genus Carduelis. Numbers on nodes represent bootstrap values. The tree was rooted using house finch (Carpodacus mexicanus) as an outgroup. 


\section{RESULTS AND DISCUSSION}

The population of the western Hemisphere (hereby referred as 'America') by Genus Carduelis birds occurred in three rapid radiations: a Mesoamerican Goldfinch Radiation (so we call it although most species also thrive in North America and C. psaltria distribution reaches Peru though the Andean spine) with C. lawrencei being the oldest extant species and a second one subdivided in two: the North American Siskin Radiation with C. spinus as an ancestor although they also comprise Caribbean and Guatemala Altiplano species, and the South American Siskin Radiation, fathered by C. notata.

\section{Origin of the Radiations (Figs. 1, 2)}

Fig. (1) shows the result of a BI phylogram performed with selected Carduelis species from all continents where this genus is present. Maximum Likelihood and Neighbour Joining analyses gave the same results (not shown). Cyt-b genes from American Carduelis finches seem to be closely related to those of Linnet (C. cannabina) and Twite (C. flavirostris), from which they separated around 5 MYA [15]. The hypothetical ancestral form(s) that gave rise to all American Carduelis species are unknown.

Fig. (2) Represents another cyt-b Bayesian tree, including only Carduelis species thriving in the American continent, using a Eurasian Carduelis species (C. carduelis) as outgroup. Genetic distances are displayed.

The common precursor of South and North American radiations i.e. the link between C. spinus and C. notata, is missing, as well as the common ancestor of all three radiations. Considering the large sampling scope we can consider them extinct. Also, and due to the mostly humid tropical weather in Central America and the poor fossilization power of these animals, it still be unlikely to find any fossil remains from the ancestral forms. The question that arises is whether the whole American group is monophyletic, or else it comes from three different non-American precursors. Out of the genetic data, we assume Eurasian siskin (C. spinus) could be the ancestor of the North American Goldfinch Radiation, because it is the only one Eurasian Carduelis that has a clear and distinct genetic relationship with one of the three extant Carduelis species belonging to this radiation [8, $15,16,22,23]$.

C. lawrencei and C. notata, precursors of the Mesoamerican Goldfinch Radiation and the South American Siskin Radiation respectively, have lost a genetic link with $C$. spinus if they ever had one. However a particular Major Histocompatibility Complex protein allele (Arnaiz-Villena et al. unpublished), which was present in a C. spinus (2.7 MYA) individual from the Pyrenees Mountains (North Spain) was also present in $C$. atrata (0.5 MYA), an endemic South American siskin living at 5000 meters of altitude around Titicaca Lake and close-by areas [23].

Nowadays the Eurasian Siskin does not thrive in America, but in easternmost and westernmost Eurasia, leaving a gap between Central Russia and its easternmost range [22]. This would be a typical example of adaptative radiation caused by a North to South migration barrier (First North American Ice Shield Glaciations) and provincialism of $C$. spinus that drove evolution to create these new finch species

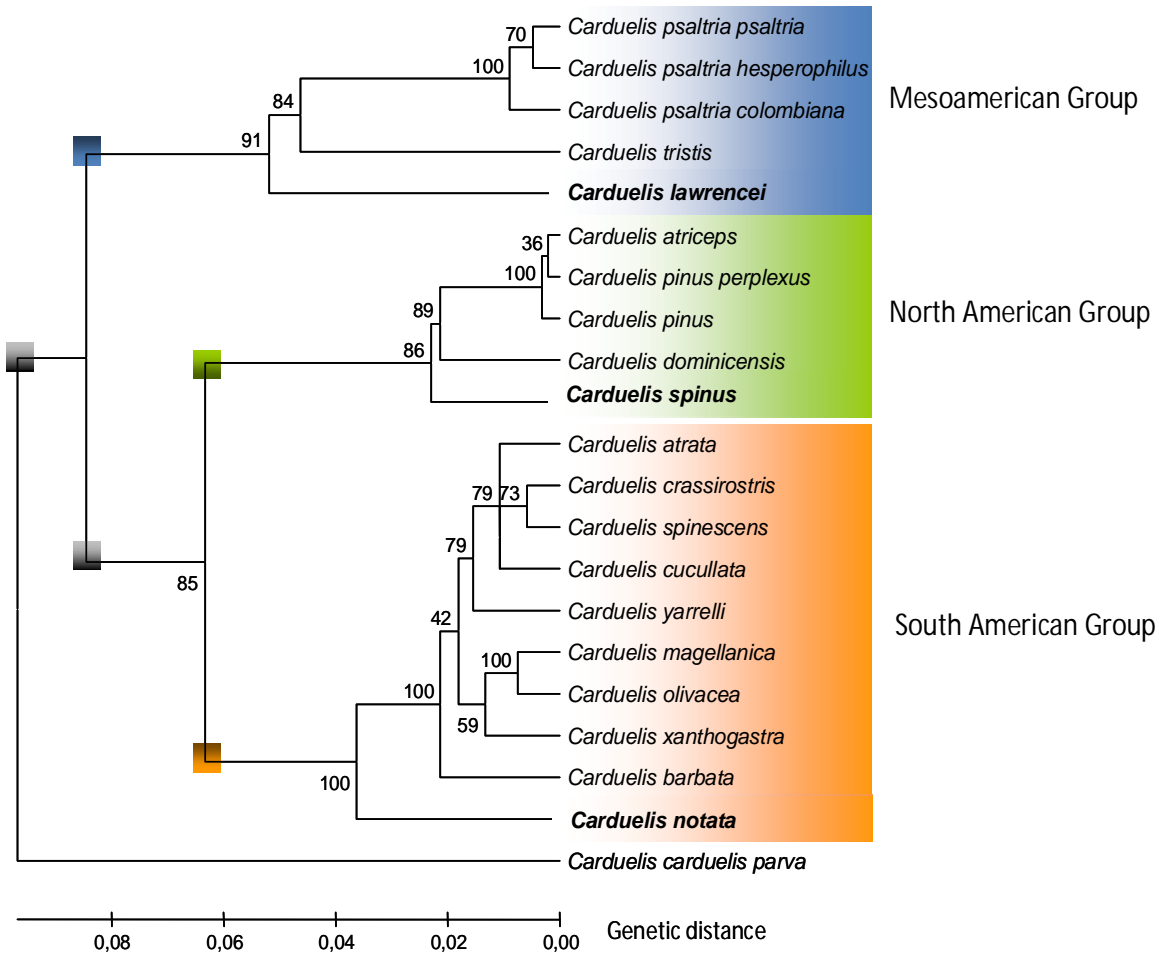

Fig. (2). Bayesian inference linearized cyt-b phylogram showing the three evolutionary radiations of North and South-American siskins. Numbers on nodes represent bootstrap values, and therefore statistical strength. The primitive form of each group is in normal case typed. The tree was rooted using Eurasian goldfinch as outgroup. Grey balls represent missing (probably extinct) links. Non extant parental species for each of the groups may have disappeared or being the ones indicated (C. lawrencei, C. spinus and C. notata). 
in Central America -C. dominicensis, C. pinus, and C. atrata - , when the last Wisconsin Glaciation ended and North American ice melted about 12,000 years ago. C. pinus would have followed the ancestral North to South migrations and covered all North America, occupying the American niches that the Eurasian Siskin couldn't reach from Asia or European coasts (see Fig. 4) during the last 2 million years because of the extant thick ice shield; neither could it afterwards because of species competition by ecologic niche with its descent $C$. pinus [22].

\section{Mesoamerican Goldfinch Radiation (Fig. 3)}

This evolutionary radiation includes $C$. tristis (American goldfinch), C. psaltria (Lesser goldfinch). and C. lawrencei (Lawrence's goldfinch). C. tristis is found in North America including parts of Mexico and the second thrives from western United States and Mexico (C. ps. hesperophilus, green back), to the Southwest United States and Central America (C. ps. psaltria), and northern South America to Peru (C. ps. colombiana): the two latter subspecies show a deep dark back and hybrids among the three subspecies with the corresponding phenotypic variability have been observed [15] Although the geographical distribution and phenotype of $C$. psaltria suggests that it could have shared a recent common ancestor with the South American siskins, our results indicate that C. psaltria is a North American bird which has colonized South American habitats and has undergone the corresponding phenotypic changes (darker in head and back). We think that it is like that because it belongs to a radiation in which Carduelis lawrencei, a North American Siskin seems to be the most ancient one. An ancestor of $C$. psaltria and C. tristis may have existed around 5 MYA; $C$. psaltria subspecies may have originated relatively recently, about 1 MYA. This subspeciation may have occurred after the closing of the Panama isthmus (5-3 MYA, Fig. 6) [15].

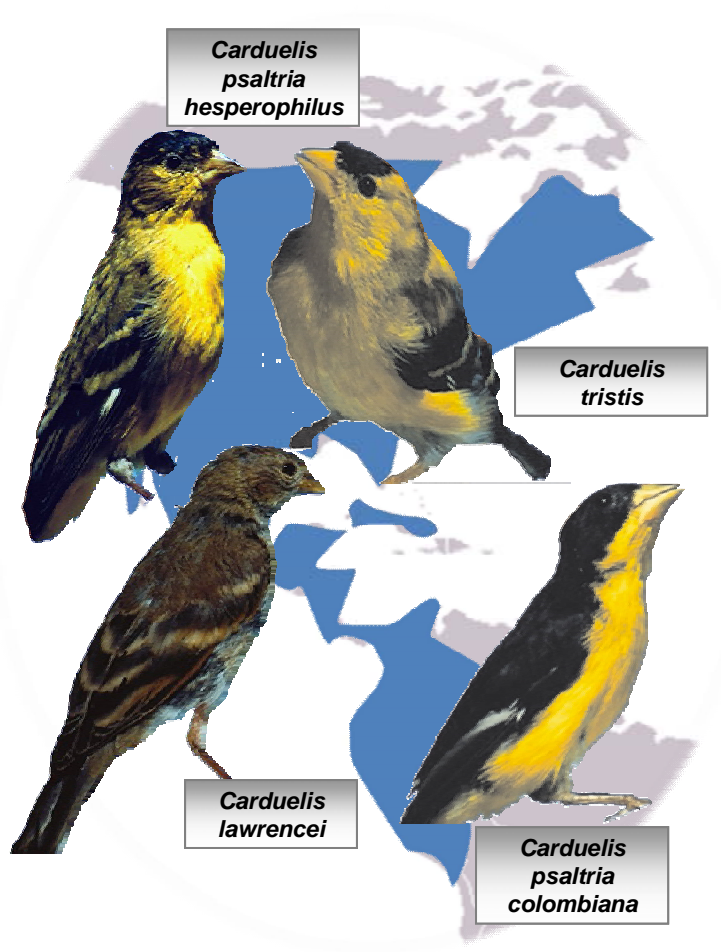

Fig. (3). The Mesoamerican Goldfinch Radiation [24,25].

\section{North American Siskin Radiation: a Eurasian Ances- tor Siskin, Carduelis Spinus [16,22] (Fig. 4)}

Siskin, North American Antillean siskin, Black-capped siskin, Pine siskin and Pine siskin perplexus form a monophyletic evolutionary group separated from other North and South American Carduelis species.

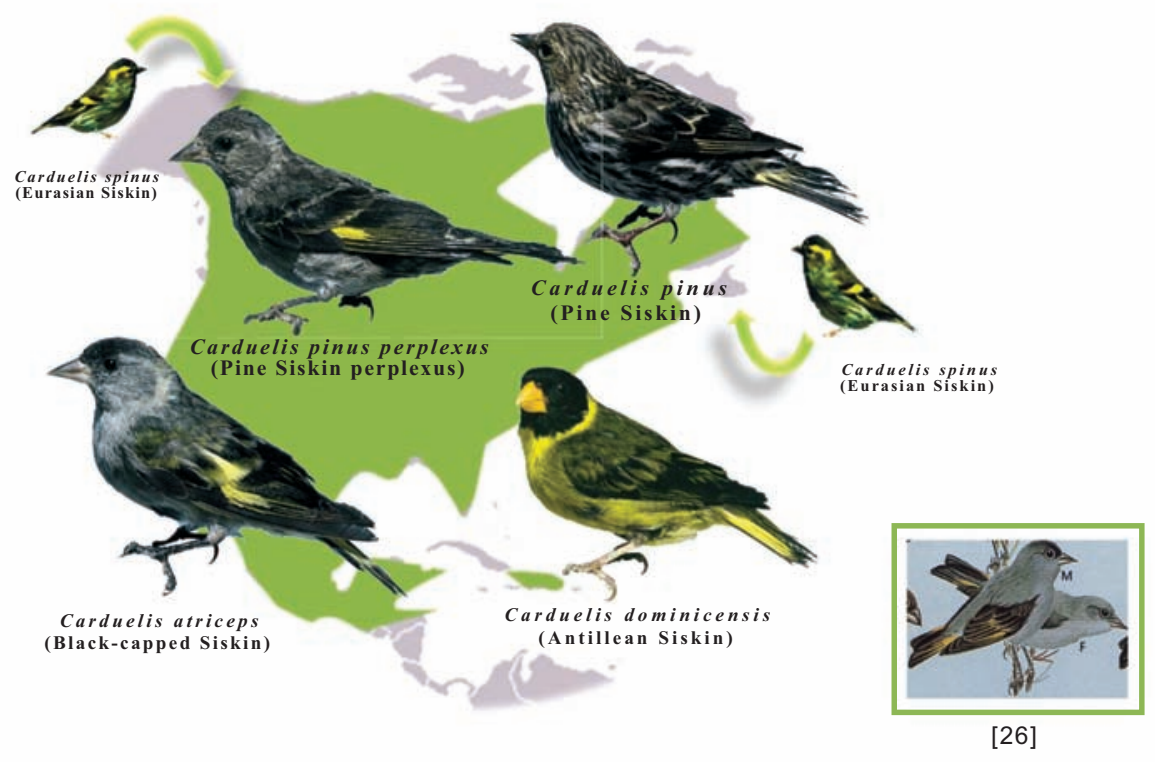

Fig. (4). The North American siskin radiation [15,16,22,23]. In Field Guide to birds of Central America [26] Preston Edwards shows a $C$. atriceps very similar to the ones defined by us. Eurasian C. spinus may have entered America both from East (Greenland, Iceland, Newfoundland) and West (Asia). 
It is suggested that easternmost Asian C. spinus passed to America through the Beringia/Aleutian Islands [27]. This information is controversial, and some authors consider them escapes from captivity [28], or misidentification of the rare Pine siskin green morph, very similar to female Eurasian siskin $[27,29]$. But two facts support the vagrancy hypothesis: a) many records are from near the Aleutian Islands; b) there are other cases of Asian birds passing through to the continent, like C. sinica, which has been seen in Alaska [30]. Vagrant birds crossing from Asia to America may be a more common phenomenon than thought therefore supporting the hypothesis of a polyphyletic origin of all American Carduelis.

After reaching the continent, during the Pliocene Epoch, C. spinus invasions from an undetermined area of the North American East coast reached the Antilles and hypothetically evolved as a geographical isolate resulting in the present $\mathrm{C}$. dominicensis. The effect of directional selection due to adaptation to new environment and genetic drift may be responsible for the very different phenotype.

Antillean siskin (C. dominicensis) is monotypic (with no subspecies) endemic to mountain pine forest of Hispaniola Island (Haiti and Dominican Republic, which are the highest mountains of the Caribbean Islands. The time of appearance of Antillean siskin seems to be 2 MYA, in the Pliocene Epoch, about the time of the Panama's Isthmus closure. The geographical distribution of Antillean siskin is the most peripheral of the group and relatively close to that of Blackcapped siskin [15].

It seems that Antillean siskin would be the oldest of the North American birds in this group (Fig. 1) and that had given rise to pine siskin. Most of the $C$. dominicensis particular traits (black head and neck, yellow breast) are shared with other forest or highland birds like C. notata (Black-headed siskin) or Linurgus olivaceus (Oriole finch) [15,31]. Thus, these head and colour traits in Antillean siskin might be due to convergent evolution on a highland forest (Fig. 1).

Pine siskin was first described by Wilson. This species thrives in North America from Alaska, South to Guatemala. Its origin could be postulated about 200,000 YA, in the late Pleistocene. This species has already been described as a sister taxa of the C. spinus [15]. Their common ancestor most likely originated in the northern Hemisphere [15].

C. pinus perplexus is resident below the Mexican Isthmus in the highlands $(2,000-3,500 \mathrm{~m})$ from northern Chiapas to western Guatemala [15]. It seems to be a sister species to Black-capped siskin (C. atriceps) based on genetic distances [15] and morphology.

The other member of the radiation, the Black-capped siskin (C. atriceps) comes from the highlands of Chiapas, southeast México, south to the western highlands of Guatemala. Black-capped siskin (C. atriceps) also seems to be a sister species of $C$. pinus, they diverged later than 200.000 years ago (Figs 1, 2).

\section{Carduelis Pinus Green Morphs and Carduelis Atriceps}

It is clear for us that C. atriceps is an overall grey bird. Notwithstanding it was described as green-backed near Quetzaltenango [32].
Our C. atriceps samples were obtained in full breeding season near Quetzaltenango (Xela). Thus, they were not migratory birds.

In addition, the most specialized bird guide for the area describes C. atriceps male exactly as our Fig. (4) inset. It is scanned from this guide [26].

However, primarily undefined green birds similar to Carduelis have been obtained accidentally in Sierra de los Chucumatanes (northern Guatemala Altiplano) by Borja Mila and they had a genetic profile identical to C. pinus (personal communication).

Since our C. atriceps samples were genetically distinct from $C$. pinus [16], we support the hypothesis that $C$. atriceps is a grey bird genetically close to C. pinus $[23,26]$.

Indeed, C. pinus green morphs have previously been described in New York area (in Schenectady) [33]. Green morphs were mostly males with back in brilliant green and distinctively different from typical brown morphs. A different appearance of green morphs in Schenectady (New York State) according to time of year was observed: March, April and May was the peak of recorded green morphs [33]. One of the green morph banded by Yunnick was found $1437 \mathrm{~km}$ South-Southeast at Darien town (Georgia, USA).

Thus, it is possible that this type of Pine Siskin green morphs may also be found at Guatemala highlands (see above). This may have been mistakenly led to describing $C$. atriceps as green, while in fact being a $C$. pinus green morph. Other authors have also recorded green morphs in New York State [34]. Thus, we favour the hypothesis that $C$. atriceps first description [32] was a Pine siskin green morph because this green morphs have a genetics identical to $C$. pinus and different to grey $C$. atriceps $[16,23,26]$ (see Fig. 4).

\section{Where American Siskins (Genus Carduelis) Do Come From?}

In a previous paper [22], it was hypothesized that the extinct parental species of genus Carduelis was originated by C. spinus coming into America from the West (Asia). However, observations of Eurasian siskins have been recorded between 1962 and 1988 several times in eastern United States and Canada [27]. Whether they were imported and escaped or not is not yet established [27]. However, others have reported these birds in Canada, Labrador Peninsula and other eastern American places close to St Lawrence River mouth. The timing of these observations goes from 1988 till 2008 [35]. Therefore, it is possible that the primitive parental species $C$. spinus entrance to America came also through the East (Greenland, Iceland, Newfoundland) being possible both East and West entrances (see Fig. 4). C.spinus is regularly found in Iceland [35].

\section{South American Siskin Radiation: a North American Ancestor, Carduelis Notata [15] (Fig. 5)}

The extant parental species, C. notata, thrives in Mexican mountains and itself or some extinct ancestor successfully colonized South America about 3 MYA (million years ago), giving rise to the South American siskin radiation. They show very close molecular and phenotypic relationships 


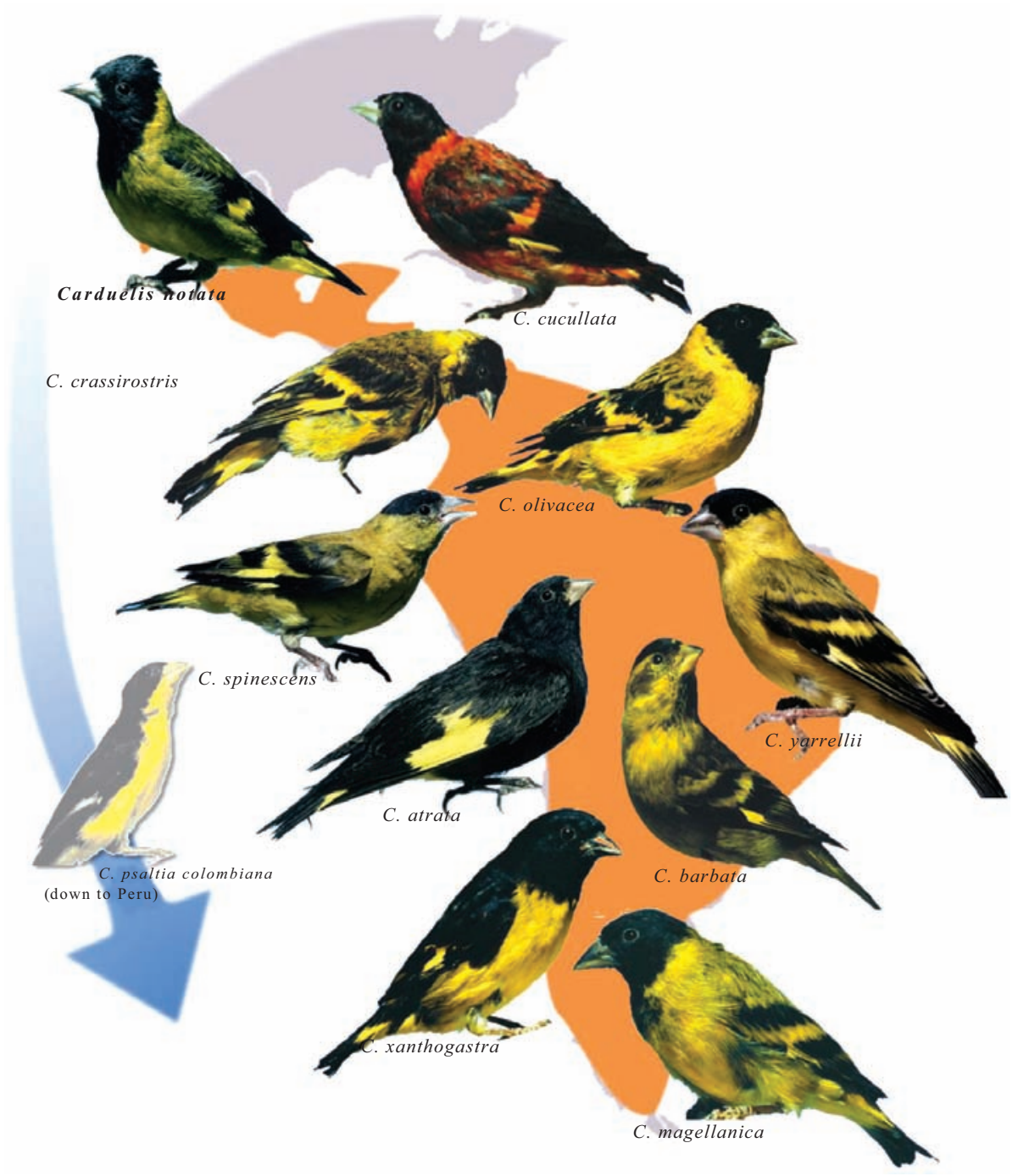

Fig. (5). The South American siskin radiation [15,16,36]. Note that C. psaltria is a North American bird which has colonized South America reaching North Peru.

(particularly colour distribution and bill shape) and probably originated quite rapidly after the Isthmus of Panama emerged. This is an example of a quick siskin radiation probably due to rapid dispersal into the South American island (isolated between 9.5 and 5-3 MYA) which had recently joined the north; although small birds can fly long distances, it is possible that the South American Carduelis radiation occurred only when mesothermal plants (the main food source of genus Carduelis) from the Rocky Mountains invaded the Andean spine after the emergence of the Isthmus of Panama (Fig. 6).

\section{CONCLUSIONS}

Three different and apparently parallel North and South American siskin evolutionary radiations have occurred in the last five million years. All three are genetically related to Linnet and Twite according to cyt-b BI phylogram $[8,15]$, but the actual common ancestor, if any, is missing.

1. The North American Goldfinch Radiation. Eurasian siskin (C. spinus) gave rise to pine siskin (C. pinus, $C$. pinus perplexus), Antillean siskin (C. dominicensis), and
Black-capped siskin (C. atriceps), which is a pine siskin sister species.

2. The $C$. pinus green morphs are most likely the first described C. atriceps [32], which is overall grey $[15,16,23,26]$.

3. Eurasian siskin (C. spinus) may have entered America from both East and West.

4. The Mesoamerican Goldfinch Radiation. Comprises Lawrence's goldfinch (C. lawrencei), Dark-backed goldfinch -C. psaltria hesperophilus (western USA, not black, but green back), C. psaltria psaltria (varied degree of black on back), and C. psaltria colombiana (very dark back, range extending through Central to South American Andes down to northern Peru)_- The ancestor of this group which most likely linked it with $C$. spinus has disappeared - our own Major Histocompatibility Complex (MHC) data, unpublished-.

5. The South American Siskin Radiation. Black-headed siskin (C. notata) from the Mexican mountains gave rise to the South American radiation of siskins. This hap- 

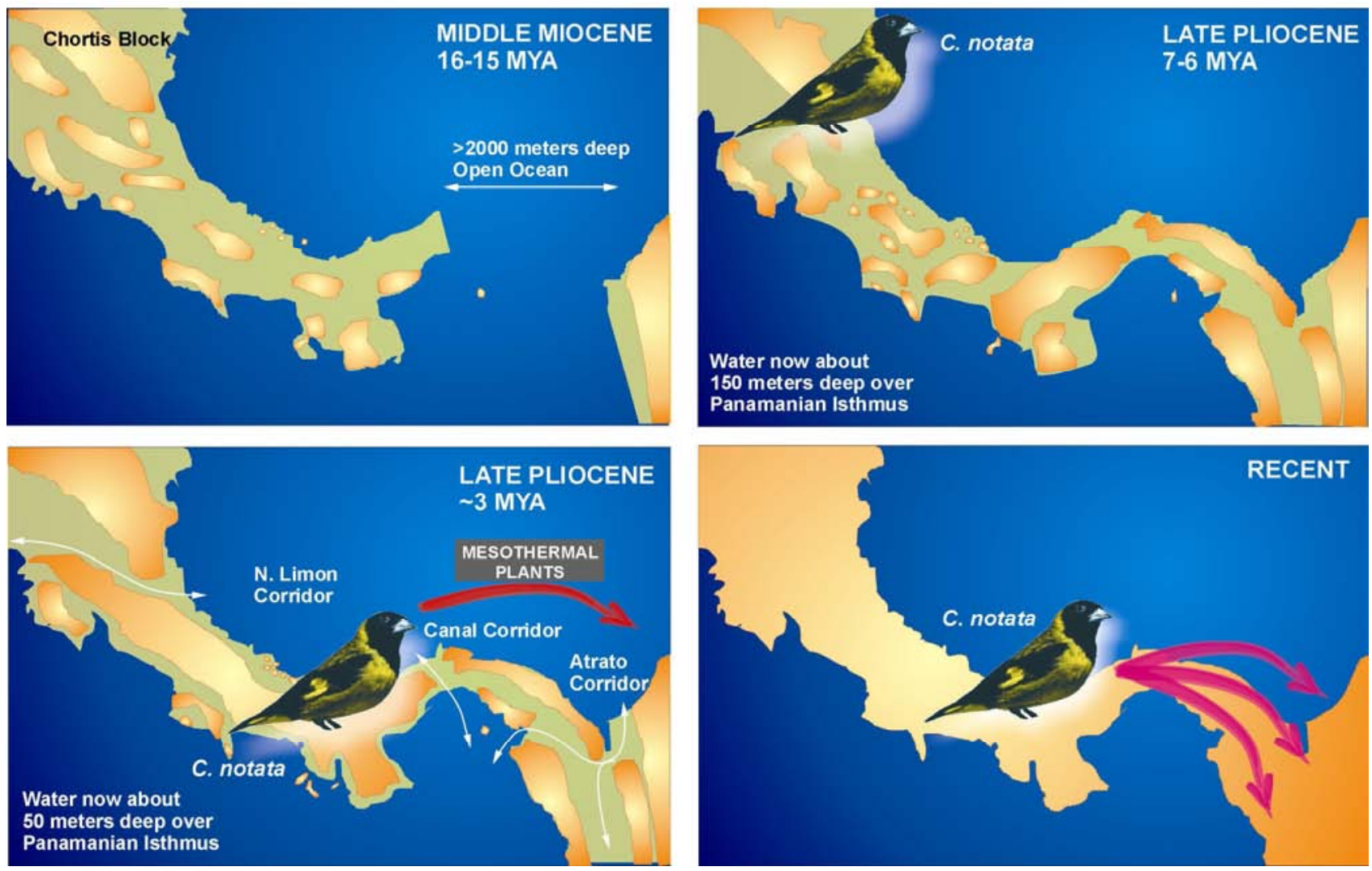

Fig. (6). South America population hypothesis. Panama Isthmus closed at least 6 MYA (million years ago), but Black-headed siskin (or its extinct ancestor) only passed through 3 MYA, when the mesothermal plants on which it feeds established in the southern American continent.

pened after 3 MYA when Panama Isthmus closed and mesothermal plants, appropriate for siskin feeding, passed to the Andean Spine. C. notata's link to C. spinus is also missing, but MHC data links $C$. notata with $C$. spinus and South American siskins, particularly with Black siskin (C. atrata unpublished).

\section{ABREVIATIONS}

$\begin{array}{lll}\text { BI } & = & \text { Bayesian inference } \\ \text { EDTA } & = & \text { Ethylenediaminetetraacetic acid } \\ \text { ML }= & \text { Maximum Likelihood } \\ \text { MYA }= & \text { Million years ago } \\ \text { cyt-b }= & \text { Mitochondrial cytochrome b=mtDNA cyt-b } \\ \text { PCR }= & \text { Polymerase chain reaction }\end{array}$

\section{CONFLICT OF INTEREST}

The authors confirm that this article content has no conflicts of interest.

\section{ACKNOWLEDGEMENTS}

This work was supported in part by grant PI11-807 from the Spanish Ministry of Health (FISS) and Mutua Madrileña Automovilistica grants. Photographs were taken by Antonio Arnaiz Villena.

\section{REFERENCES}

[1] Pasquet E, Thibault JC. Genetic differences among mainland and insular forms of the Citril Finch Serinus citrinella. Ibis 1997; 139: 679-84.

[2] Sibley CG, Ahlquist J. Phylogeny and classification of birds. New Haven, Conn.:Yale University Press 1990.

[3] Haavie J, Borge T, Bures S, et al. Flycatcher song in allopatry and sympatry convergence, divergence and reinforcement. J Evol Biol 2004; 17: 227-37.

[4] Kusmierski R, Borgia G, Uy A, Crozier RH. Labile evolution of display traits in bowerbirds indicates reduced effects of phylogenetic constraint. Proc Biol Sci 1997; 264: 307-13.

[5] Marchetti K. Dark habitats and bright birds illustrate the role of the environment in species divergence. Nature 1993; 362: 149-52.

[6] McCracken KG, Harshman J, McClellan DA, Afton AD. Data set incongruence and correlated character evolution: an example of functional convergence in the hind-limbs of stifftail diving ducks. Syst Biol 1999; 48: 683-714.

[7] van Tuinen M, Butvill DB, Kirsch JA, Hedges SB. Convergence and divergence in the evolution of aquatic birds. Proc Biol Sci 2001; 268: 1345-50.

[8] Arnaiz-Villena A, Guillen J, Ruiz-del-Valle V, et al. Phylogeography of crossbills, bullfinches, grosbeaks, and rosefinches. Cell Mol Life Sci 2001; 58: 1159-66.

[9] Armani GC. Guide des Passereaux Granivores. Paris: Delachaux et Niestlé 1983.

[10] Clement P, Harris P, Davies J. Finches and Sparrows. London: Princeton University Press 1993.

[11] Sibley CG, Monroe BL Jr. Distribution and Taxonomy of Birds of the World. New Haven and London: Yale University Press 1990.

[12] Friesen VL, Montevecchi WA, Baker AJ, Barrett RT, Davidson WS. Population differentiation and evolution in the common guillemot Uria aalge. Mol Ecol 1996; 5: 793-805.

[13] Questiau S, Eybert MC, Gaginskaya AR, Gielly L, Taberlet P. Recent divergence between two morphologically differentiated 
subspecies of bluethroat (Aves: Muscicapidae: Luscinia svecica) inferred from mitochondrial DNA sequence variation. Mol Ecol 1998; 7: 239-45.

[14] Howell S, Webb S. A guide to the birds of Mexico and Northern Central America. Oxford (UK):Oxford University Press 1995.

[15] Arnaiz-Villena A, Alvarez-Tejado M, Ruiz-del-Valle V, et al. Phylogeny and rapid northern and southern hemisphere speciation of goldfinches during the Miocene and Pliocene epochs. Cell Mol Life Sci 1998; 54: 1031-41.

[16] Arnaiz-Villena A, Ruiz-del-Valle V, Moscoso J, Serrano-Vela JI, Zamora J. mtDNA phylogeny of North American Carduelis pinus group. Ardeola 2007; 54: 1-14.

[17] Sambrook J, Fritsch EF, Maniatis T. Molecular cloning: a laboratory manual. New York: Cold Spring Harbor Laboratory Press 1989.

[18] Kocher TD, Thomas WK, Meyer A, et al. Dynamics of mitochondrial DNA evolution in animals: amplification and sequencing with conserved primers. Proc Natl Acad Sci USA 1989; 86: 6196-200.

[19] Kumar S, Tamura K, Nei M. MEGA3: Integrated software for Molecular Evolutionary Genetics Analysis and sequence alignment. Brief Bioinform 2004; 5: 150-63.

[20] Ronquist F, Huelsenbeck JP. MrBayes 3: Bayesian phylogenetic inference under mixed models. Bioinformatics 2003; 19: 1572-4.

[21] Thorne JL, Kishino H, Painter IS. Estimating the rate of evolution of the rate of molecular evolution. Mol Biol Evol 1998; 15: 164757.

[22] Arnaiz-Villena A, Ruiz-del-Valle V, Reguera R, Gomez-Prieto P, Serrano-Vela JI. What might have been the ancestor of New World siskins? Open Ornithol J 2008; 1: 46-7.

[23] Arnaiz-Villena A, Ruiz-del-Valle V, Gomez-Prieto P. Phylogeography of finches and sparrows In: Rechi L, Ed. New York, Nova Science 2009; pp. 1-54. Free download from: https://www. novapublishers.com/catalog/product_info.php?products_id=13642

[24] Avibase - The World Bird Database. Lepage, D: 2012 [updated 2012 July 12; cited 2012 July 15]. Availabe from: http://avibase.
bsceoc.org/species.jsp?lang=ES\&avibaseid=9820CECA12EC737D \&sec $=$ map

[25] Ridgely R, Allnutt T, Brooks T, et al. Nature Serve Explorer: Digital Distribution Maps of the Birds of the Western Hemisphere. [1.0]. Nature Serve, Arlington, Virginia, USA 2003.

[26] Preston Edwards E. A field guide to the birds of Mexico and Adjacent Areas: Belize, Guatemala and El Salvador. $4^{\text {th }}$ ed. Austin, Texas: University of Texas Press 2005.

[27] McLaren I, Morlan J, Smith P, Gosselin M, Bailey S. Eurasian siskins in North America - distinguishing females from green-morp Pine Siskins. Am Birds 1989; 43: 1268-74.

[28] American Ornithologists Union. Check-list of North American birds. $6^{\text {th }}$ ed. Lawrence, Kansas: Allen Press 1983.

[29] Ridgway R. The birds of North and Middle America. Part I. Family Fringillidae - the finches. Number 50, Part 1 of Bulletin of the United States National Museum. 50 ${ }^{\text {th }}$ ed. Washington: U.S. Government Printing Office 1901.

[30] Gibson D, Heinl S, Tobish T. Checklist of Alaska birds. Fairbanks: University of Alaska Museum 2008.

[31] Arnaiz-Villena A, Moscoso J, Ruiz-del-Valle V, et al. Bayesian phylogeny of Fringillinae birds: status of the singular African Oriole Finch (Linurgus olivaceus) and evolution and heterogeneity of genus Carpodacus. Acta Zoologica Sinica 2007; 53: 826-34.

[32] Salvin O. Proceedings of the scientific meetings of the zoological society of London. London: Academic Press 1863; p. 190.

[33] Yunick RP. The occurrence of green-morph Pine Siskins in the Siskin irruption of 1989-1990. North Am Bird Bander 1996; 21 : 85-7.

[34] Boyle WI Jr, Paxton RO, Cutler DA. Hudson-Delaware region of the changing seasons. American Birds 1990; 44: 245.

[35] Mactavish B. Atlantic Canada [bird sightings]. North Am Birds 2008; 64: 560-1.

[36] Zamora J, Moscoso J, Ruiz-del-Valle V, et al. Conjoint mitochondrial phylogenetic trees for canaries (Serinus spp.) and goldfinches (Carduelis spp.) show several specific polytomies. Ardeola 2006; 53: 1-17. 